\title{
Financial Position and Sustainability of Associations in Croatia ${ }^{1}$
}

\author{
Davor Vašiček \\ University of Rijeka, Faculty of Economics and Business, Croatia \\ davor.vasicek@efri.hr \\ https://orcid.org/0000-0001-9493-264X
}

\author{
Ana Marija Sikirić \\ University of Rijeka, Faculty of Economics and Business, Croatia \\ ana.marija.sikiric@efri.hr \\ https://orcid.org/0000-0002-8408-586X \\ Martina Dragija Kostić \\ University of Zagreb, Faculty of Economics and Business, Croatia \\ mdragija@efzg.hr \\ https://orcid.org/0000-0003-0131-0345
}

Received: 12. 7. 2018

Accepted: 18. 1. 2019

\section{ABSTRACT}

This paper emphasizes the economic importance of the civil society sector in the national socio-economic context. There is a systematic neglect of the economic and financial components of civil society organizations and non-profit sector in Croatia even though a significant volume of civil society organizations' activities is funded from public sources and there is a high possibility of exploitation of their relatively privileged tax position. The purpose of this paper is to present research results of the funding sources, the financial potential and the elements of economic performance of citizens' associations in the Republic of Croatia. The survey sample includes over 20,000 citizens' associations which have submitted financial reports to the Registry of Non-profit Organizations in accordance with the statutory obligation. The research is based on aggregated data reported in the Balance Sheet and Performance Report for 2015 and 2016. The scientific contribution of the paper is reflected in the assessment of the financial performance and financial transparency of the activities of civil society organizations in the Republic of Croatia and their sustainability in comparison with Serbia and Slovenia.

1 This article is a revised version of the paper entitled 'Financial position and sustainability of associations in Croatia' presented at International Scientific Conference Economics of Digital Transformation (EDT) 2018 DIGITOMICS, Rijeka Croatia, 2-4 May 2018. The EDT contributions are not publicly available. 
Keywords: associations, civil society, financial position, funding sources, performance, Croatia, Serbia, Slovenia

JEL: G34, M14, M41

\section{Introduction}

Development, performance and importance of civil society organizations in wider society is usually measured and evaluated using non-financial, qualitative criteria of their impact on narrow interest groups and their contributions to the development of society as a whole. While economic and financial component of civil society organizations and non-profit sector is neglected not only in professional analyzes and scientific research, but also for the purposes of macroeconomic management at the national level.

Activities of non-profit sector attract public and regulator's attention only sporadically in the context of major political campaigns, large-scale humanitarian actions or financial affairs involving prominent public figures. There is systematic neglect of the fact that a significant volume of civil society organizations activities are funded from public sources and that there is high possibility of the exploitation of their economic and financial unattractiveness and their relatively privileged tax position.

For these reasons, the main aim of this paper is to answer the question what is economic strength, financial position and financial performance of the citizen's associations as the most important group of civil society organizations in Croatia and are available funding sources satisfactory for sustainable development and long-term stability of civil society organizations. Some of the key indicators of financial position and financial performance of associations and non-governmental non-profit sector in the Republic of Croatia will be presented based on the analysis of the aggregated data reported in the Balance Sheet and Performance Report for years 2015 and 2016. The survey sample includes over 20,000 associations of citizens and their associations which have submitted financial reports to the Registry of Non-profit Organizations in accordance with the statutory obligation.

For overview of the sample quality, scope of non profit sector, and in particular the formal-legal framework and territorial distribution of its most significant segment - citizens' associations and their alliances, will be presented in the paper. Special focus in the research will be put on funding associations activities from public sources.

\subsection{The scope of non-profit sector in Republic of Croatia}

The characteristics of a non-profit organization do not necessarily depend on its legal form, i.e. the activities and the purposes of the organization are more important than the character of its legal identity. Non-profit organization is defined as a legal entity whose purpose and objectives of establishment and functioning are not directed towards profit generation, but towards satisfying general interests and common needs of the wider community (Vašiček 
and Vašiček, 2016, p. 6). Governmental non-profit organizations also meet this definition, but since as budget users they are merely funded from budget they are part of the public sector, not non-profit sector ${ }^{2}$. According to international statistical classification ${ }^{3}$ non-profit sector includes only nongovernmental nonprofit organizations founded on a private initiative that are dominantly financed through donations, grants, membership contributions and other similar specific forms of financing that are, as a rule, based on voluntary and humane grounds (European Commission, 2010, pp. 545-546). So, non-profit sector in Croatia includes (Croatian Bureau of Statistics, ny):

1. Trade unions, professional or school associations, consumer associations, political parties, churches or religious associations (including those financed but not controlled by the state), and social, cultural, recreational and sports clubs;

2. Charitable organizations, aid providing organizations that are financed through voluntary transfers in cash or noncash transfers from other institutional units.

However, according to the Act on Financial Operations and Accounting of Non-Profit Organizations (Official Gazette 121/2014), the non-profit sector of the Republic of Croatia, with the exception of civil society organizations (non-governmental domestic and foreign associations and their alliances, trusts, foundations, art associations, trade unions, employer associations) also includes all other legal entities that are non-profit by nature, although they are founded and financed under special regulations (institutions, chambers, ...). Except for the proclaimed non-profit character, the common denominator of these entities is a unified system of accounting and financial reporting through the Register of Non-profit Organizations (in text: RNO) managed by the Ministry of Finance in common.

Because of the heterogeneity and the broad scope of the non-profit sector in Republic of Croatia, the focus of the analysis is on the economic and financial potential of associations and their alliances, which according to current data from the RNO make up 33,191 organizations out of 35,780 non-profit organizations or more than $92 \%$ of the non-profit sector of the Republic of Croatia ${ }^{4}$.

\subsection{Citizens' associations in the Republic of Croatia}

Associations are the most common form of organized voluntary organization of civil society that allow individuals to step out of their private sphere of

2 See more on: Croatian Bureau of Statics: Sektorska klasifikacija institucionalnih jedinica, (S.13), <http://www.dzs.hr/app/sektorizacija/Documentation/SektorskaKlasifikacija.pdf> and The Rulebook on Determining Budget and Extra-budgetary Users of the State Budget and Budget and Extra-budgetary Users of the Budget of Local and Regional Self-Government Units and on the Method of Keeping the Register of Budgetary and Extra-budgetary Users, Official Gazette $128 / 09,142 / 14$

3 European Commission, EUROSTAT, European system of accounts - ESA 2010, Classification of the purposes of non-profit institutions serving households (COPNI), <http://ec.europa.eu/ eurostat/web/products-manuals-and-guidelines/-/KS-02-13-269>, pp. 545-546

4 Only organizations that have fulfilled their legal obligation to register in the Register are included. 
family and/or professional life without leaving them and influence on how common and public functions are fulfilled. Law on Association (Official Gazette $74 / 17,70 / 17$ ), which regulate the establishment, registration, legal status and termination of existence of associations, as well as the registration and termination of activities of foreign associations in the Republic of Croatia, define association as any form of a free and voluntary association of several natural or legal persons, who shall, in order to protect their benefits or stand ups for the protection of human rights and freedoms, as well as the ecological, humanitarian, information, cultural, ethnic, pro-natality, educational, social, professional, sports, technical, health, scientific or other believes and goals that are not in contravention of the Constitution, without an intention of gaining profit, comply with the rules that regulate the organization and activities of such a form of association.

The Association as a non-profit organization does not perform its activities with the purpose of gaining profit for its members or third parties. However, the non-profit character of the association does not mean that the association can not engage in social entrepreneurship, i.e. associations can perform revenue-generating activities (in the market), but the revenue generated must exclusively be used for the performance and improvement of the activities of the association that enable achieving goals set by the statute. In that way, a non-profit organization is not limited to earn income by performing "profitable" activities.

Legislative regulation on the "profit" activity of a non-profit organization is based on assumption that these activities make relatively small part of overall economic activity which, in spite of the tax-privileged position of non-profit organizations, does not disturb market competition, and that income earned in those activities is intended to be consumed in accordance with the activity of non-profit organizations, and not for making profit. Nevertheless, in spite of the public benefit of its activity, the association becomes a taxpayer when it continuously performs more significant scope of market activities with the aim of gaining economic benefits, thus seeking to eliminate its relatively privileged tax position in compare to other economic entities 5 .

The association acquires its legal personality by registration in the Register of Associations of the Republic of Croatia managed by the Ministry of Public Administration. According to official data, on June 302017 there were 52,227 associations registered in the Register of Associations (Ministry of Public Administration, 2017). This number also includes associations which are considered inactive because not convening assembly for more than eight years. Currently, based on that criteria, there are even 24,440 associations in Register ( $46.8 \%$ of total registered associations) that are considered inactive. In the context of the application of the Law on Association, 25,109 associations have aligned their statutes with the provisions of the Law on Association, and for 4,637 associations the statute is in the process of harmonization.

5 See more: Instructions from the Central Tax Administration Office, KLASA: 410-01/1501/1590, URBROJ: 513-07-21-01/15-1 
Table 1: Number of associations in Republic of Croatia on June 302017

\begin{tabular}{|c|c|c|c|c|c|c|}
\hline \multirow[b]{2}{*}{ City of Zagreb } & \multirow{2}{*}{$\begin{array}{c}\text { Number of } \\
\text { registered } \\
\text { associations } \\
\quad 12,500\end{array}$} & \multirow{2}{*}{$\begin{array}{c}\text { Number of } \\
\text { associations } \\
\text { per } 1.000 \\
\text { inhabitants } \\
15.8\end{array}$} & \multicolumn{4}{|c|}{$\begin{array}{l}\text { Of the total number of registered } \\
\begin{array}{c}\text { Associations that } \\
\text { have aligned }\end{array} \text { Inactive } \\
\text { their statutes }\end{array}$} \\
\hline & & & 4,410 & $35.3 \%$ & 6,519 & $52.2 \%$ \\
\hline Dubrovnik-Neretva & 1,934 & 15.8 & 1,032 & $53.4 \%$ & 899 & $46.5 \%$ \\
\hline Istria & 3,008 & 14.5 & 1,298 & $43.2 \%$ & 1,387 & $46.1 \%$ \\
\hline Primorje-Gorski Kotar & 4,082 & 13.8 & 1,909 & $46.8 \%$ & 1,701 & $41.7 \%$ \\
\hline Osijek-Вaranja & 3,896 & 12.8 & 2,392 & $61.4 \%$ & 1,569 & $40.3 \%$ \\
\hline Lika-Senj & 647 & 12.7 & 392 & $60.6 \%$ & 348 & $53.8 \%$ \\
\hline Šibenik-Knin & 1,344 & 12.3 & 695 & $51.7 \%$ & 719 & $53.5 \%$ \\
\hline Bjelovar-Bilogora & 1,386 & 11.6 & 893 & $64.4 \%$ & 656 & $47.3 \%$ \\
\hline Koprivnica-Križevci & 1,323 & 11.4 & 759 & $57.4 \%$ & 406 & $30.7 \%$ \\
\hline Karlovac & 1,439 & 11.2 & 897 & $62.3 \%$ & 601 & $41.8 \%$ \\
\hline Požega-Slavonia & 852 & 10.9 & 556 & $65.3 \%$ & 369 & $43.3 \%$ \\
\hline Split-Dalmatia & 4,863 & 10.7 & 2,872 & $59.1 \%$ & 2,525 & $51.9 \%$ \\
\hline Zadar & 1,762 & 10.4 & 824 & $46.8 \%$ & 778 & $44.2 \%$ \\
\hline Međimurje & 1,162 & 10.2 & 841 & $72.4 \%$ & 418 & $36.0 \%$ \\
\hline Brod-Posavina & 1,607 & 10.1 & 797 & $49.6 \%$ & 894 & $55.6 \%$ \\
\hline Varaždin & 1,778 & 10.1 & 1,162 & $65.4 \%$ & 612 & $34.4 \%$ \\
\hline Virovitica-Podravina & 839 & 9.9 & 596 & $71.0 \%$ & 354 & $42.2 \%$ \\
\hline Sisak-Moslavina & 1,696 & 9.8 & 1,211 & $71.4 \%$ & 710 & $41.9 \%$ \\
\hline Zagreb & 3,103 & 9.8 & 1,892 & $61.0 \%$ & 1,685 & $54.3 \%$ \\
\hline Vukovar-Syrmia & 1,752 & 9.8 & 1,208 & $68.9 \%$ & 821 & $46.9 \%$ \\
\hline Krapina-Zagorje & 1,254 & 9.4 & 951 & $75.8 \%$ & 469 & $37.4 \%$ \\
\hline TOTAL & 52,227 & 12.2 & 27,587 & $52.8 \%$ & 24,440 & $46.8 \%$ \\
\hline
\end{tabular}

Source: authors calculations based on data from Register of Associations of Republic of Croatia and date from Croatian Bureau of Statistics (Population contingents, by towns/municipalities, Census 2011) 
The number of associations, as an important form of civil society organization, is a good indicator of the social activities of citizens, their involvement in social processes and the level of social capital (Putnam, 2000 and Deakin, 2001 according to Bežovan, 2002, p.66). Since the number of associations is often used as the main indicator of civil society development, Table 1 shows the total number of associations, the number of associations per 1,000 inhabitants, the absolute and relative share of associations that have aligned their statutes and absolute and relative share of associations that are officially considered inactive in the each county of the Republic of Croatia in 2017.

According to data from Table 1, the average number of associations per 1.000 inhabitants in the Republic of Croatia is 12.2 and ranges from 15.8 in the City of Zagreb and the Dubrovnik-Neretva County to 9.4 in the County of Krapina-Zagorje. There are only $35.3 \%$ of associations in the City of Zagreb that have aligned their statutes, and even $52.2 \%$ of associations are considered inactive because not convening assembly in last eight years. In contrast, in the Krapina-Zagorje County even $75.8 \%$ of associations have align its statutes, and only $37.4 \%$ of associations are considered inactive. Counties, which according to the number of associations per 1,000 inhabitants recorded above average civil society activity in the Republic of Croatia, excluding City of Zagreb and the Dubrovnik-Neretva County, are: Istria, Primorje-Gorski Kotar, Osijek- Baranja, Lika-Senj and Šibenik-Knin County. The lower level of civil society activity is recorded in the Krapina-Zagorje, Vukovar-Syrmia, Zagreb, Sisak-Moslavina and Virovitica-Podravina County. The largest share of inactive associations registered in the Register of Associations was recorded in Zagreb, Šibenik-Knin and Lika-Senj County, while in Krapina-Zagorje, Međimurje, Sisak-Moslavina and Virovitica-Podravina County high share of associations have aligned their statutes with the Law on Associations.

\section{Methods}

Of the total number of associations registered in the Register of Associations $(52,227)$, only 33,191 associations are also registered in the RNO managed by Ministry of Finance of the Republic of Croatia. This register is set up for the purpose of monitoring the financial performance of non-profit organizations through the data and information from annual financial statements. Given the ascertained significant number of inactive associations, it can be concluded that the number of associations signed in the RNO at the Ministry of Finance $(32,542)$ more realistically reflects the number of active associations today.

The analysis and assessment of the economic and financial potential of a citizen's association is based on information presented in financial statements. Information is generated according to nonprofit accounting system of Croatia which based on accrual accounting principle since 2008. According to the Act on Financial Operations and Accounting of Non-Profit Organizations (Official Gazette 121/2014), the reporting and accounting system is rationalized by the size and economic importance of a non-profit organization. Accounting methods and financial reporting vary based on the revenue and asset value of 
certain non-profit organizations ${ }^{6}$. So called small non-profit organizations are enabled to apply simplified cash basis accounting, while others apply accrual accounting and the system of integrated financial reporting.

Of the total number of associations registered in the RNO 54\% apply accrual accounting principle and are required to submit complete set of financial statements. The remaining $46 \%$ are so-called small associations that apply simple bookkeeping and submit only annual financial report on receipts and expenditures at the end of the year. This complicates an integrated overview and the analysis of economic strenght of the non-profit sector, because it requires the reclassification of data expressed on different methodological bases.

An analysis of the overall financial performance of the associations in the Republic of Croatia is even more complicated due to fact that only about $70 \%$ of associations registered in the RNO have fulfilled their statutory obligation to submit financial reports for 2016 , namely $75 \%$ of associations applying accrual accounting and the system of integrated financial reporting and about $65 \%$ of associations applying simplified cash basis accounting. Although the percentage of associations that had fulfilled their statutory obligation to submit financial reports has increased in comparison to 2015, the degree of transparency of financial operations and financial discipline of associations is still unsatisfactory in Croatia.

\section{Results and discussion}

Despite the fact that only $70 \%$ of associations registered in the Register of Non-profit Organization have fulfilled their statutory obligation to submit financial reports for 2016, the available data represents a valuable source of information on financial aspects of the activities of associations. Nevertheless, at the level of macroeconomic management to this group of entities is not given adequate importance. Probably because of their low fiscal potential and relatively small share of the total number of workers they employ.

\subsection{Economic and financial potential of citizens' associations in the Republic of Croatia}

Associations that are required to submit complete set of financial statements reported in aggregate Income and Expenditure Report in 2016 total revenues exceeding EUR 740 million, or 13.7\% more than in 2015 and expenditures in excess of EUR 720 million which is $9 \%$ higher than in 2015. According to date from aggregate Balance sheet, the value of the assets of associations of citizens and their alliances in the Republic of Croatia at the end of 2016 amounts to HRK 700 million, which is $4.4 \%$ higher than in the previous year.

Small associations, that apply simplified cash basis accounting, in aggregate Report of the Receipts and Expenditures in 2016 reported receipts $17.7 \%$

6 Single bookkeeping can be applied by non-profit organization whose revenue and value of asset does not exceed EUR 30,666.66 in last three years. More on non-profit accounting system in Republic of Croatia: Vašiček, V. and Vašiček, D. (2016) 
higher than in 2015 (HRK 411.6 million) and expenditures 20.1\% higher than in 2015 (HRK 400.8 million).

Human resources, especially those working for associations, are key factor for sustainability and development of the same. Employment data in 2016 (based on hours worked) show that associations in Croatia employ a total of 18,800 workers, which is $6.5 \%$ more than last year. This number of workers account for more than $0.86 \%$ of the total number of employees in the Republic of Croatia ${ }^{7}$.

The 2016 summary report shows that aggregated employment data and performance elements of associations and their alliances are steadily increasing, suggesting that in economic terms, due to their non-market orientation, unfavourable economic conditions have not adversely affected the activities of associations in the Republic of Croatia. It should also be borne in mind that, although financial reporting obligation for all non-profit entities has been introduced in 2015, still a large number of associations do not fulfil their obligation to register in the Register of Non-Profit Organizations and to submit financial reports. This makes it difficult to fully analyze and create an overall picture of economic strength of the most represented form of civil society organizations.

\subsection{The sustainability of citizens' associations in the Republic of Croatia}

Certain amount of funding is necessary to cover the costs of activities of each association. Sustainable development and long-term stability of civil society organizations are linked to possibilities of collecting necessary financial resources from different sources. Sources of financial resources required for the operation of the association are private donations of economic entities and citizens, public grants awarded by governments, counties, cities and municipalities or public companies and organizations, then membership fees or funds provided by members of individual associations and the funds allocated to them from foreign programs intended for the development of civil society (Bežovan and Ivanović, ny, pp. 38-43). The existence of various sources of funding associations' activities indicates that society has recognized the strength and important role of civil society in the development of society. Unfortunately, most of the organizations have one or two sources of funding, which, in the long run, imply a great financial instability of such organizations (Bežovan, 2004). In addition, the number of sources most often depends on the area of activity of an association (Bežovan and Ivanović, ny, pp. 38-43). Since many associations face significant financial challenges, a question remains as to how effective associations can be in their activities if much of their energy is spent in grant seeking.

In 2016, donations make up the largest proportion of sources of income for non-profit organizations (28\%), of which $60 \%$ are donations from the budget,

7 Authors Calculation based on data from Croatian Bureau of Statistics (Employed by occupation, age and sex, by towns/municipalities, Census 2011) 
followed by revenue on the basis of special regulations (27\%). Membership fees account for $14 \%$ of income, while on the basis of social entrepreneurship 19\% of revenue is generated (Vašiček, Sikirić and Čičak, 2017, p. 763). The aforementioned indicates that the financing of the non-profit sector is mostly obtained through donations. It is noticeable that the revenues of social entrepreneurship are relatively poorly represented, which leads to the conclusion that this form of action needs to be stimulated through the legal and tax system.

The Regulation on the Criteria, Standards and Procedures for Financing and Contracting Programs and Projects of Public Benefit Interest Implemented by Associations (Official Gazette 26/15) defines the standards of financing and measures that associations and other civil society organizations must fulfil when implementing programs and projects of general interest financed from public sources. One of the basic prerequisites is the registration in the RNO, which aims to increase financial transparency of the operations and activities of non-profit organizations According to the Report on the Financing of Civil Society Organizations Projects and Programmes from Public Sources in 2015, adopted by the Government in April 2017, 36.104 different programs and projects of general interest implemented by associations and other civil society organizations were financed from the public sources, and through a public call a total of HRK 223,026,557.21 was awarded by direct grants, donations and sponsorships. The amounts awarded according to the sources of funds at all levels in 2015 are shown in Table 2. 
Table 2: The amounts awarded according to the sources of funds at all levels in 2015

\begin{tabular}{|c|c|c|c|}
\hline Source of funds & $\begin{array}{l}\text { Amount awarded } \\
\quad \text { (in EUR) }\end{array}$ & $\begin{array}{l}\text { Relative } \\
\text { share } \\
\text { (in \%) }\end{array}$ & $\begin{array}{l}\text { No. of } \\
\text { projects }\end{array}$ \\
\hline TOTAL FUNDS ON NATIONAL LEVEL & $103,292,741.75$ & 46.33 & 7,540 \\
\hline $\begin{array}{l}\text { Funds from the part of the revenues from } \\
\text { games of chance }\end{array}$ & $47,965,487,49$ & 21.50 & \\
\hline Funds from the state budget & $40,660,353,07$ & 18.23 & \\
\hline EU funds & $13,320,945,83$ & 6.00 & \\
\hline $\begin{array}{l}\text { Funds from part of the income from the } \\
\text { public broadcasting company fee }\end{array}$ & $543,888,34$ & 0.24 & \\
\hline Funds from fees for environmental protection & $445,796,99$ & 0.20 & \\
\hline $\begin{array}{l}\text { Funds from other foreign funds (European } \\
\text { Economic Area countries and the Kingdom of } \\
\text { Norway) }\end{array}$ & $311,949.91$ & 0.14 & \\
\hline Non-financial funds & $44,320.12$ & 0.02 & \\
\hline $\begin{array}{l}\text { ON THE LOCAL AND REGIONAL LEVEL - } \\
\text { TOTAL }\end{array}$ & $113,262,536.37$ & 50,78 & 22,420 \\
\hline Funds from the city budgets & $52,954,371.97$ & 23.74 & 8,721 \\
\hline Funds from the budget of the City of Zagreb & $28,672,175.37$ & 12.86 & 1,814 \\
\hline Funds from the municipal budget & $18,539,057.07$ & 8.31 & 5,867 \\
\hline Funds from county budget & $13,096,931.96$ & 5.87 & 6,018 \\
\hline $\begin{array}{l}\text { Funds from the income of companies owned } \\
\text { by the Republic of Croatia and local and } \\
\text { regional self-government units }\end{array}$ & $4,164,906.44$ & 1.86 & 2,231 \\
\hline $\begin{array}{l}\text { Funds from the part of the income of tourist } \\
\text { boards }\end{array}$ & $2,255,122.97$ & 1.01 & 656 \\
\hline Total: & $222,975,307.53$ & 100.00 & 32,847 \\
\hline
\end{tabular}

Source: Office for the Cooperation with NGOs, 2017

State administration bodies, Croatian Government offices and other public institutions at the national level financed 7,540 civil society organizations' programs and projects with EUR $103,292,741.75$ in 2015 , which is $31.73 \%$ more than in 2014 when only 5,724 civil society organizations' programs and proj- 
ects were financed. The largest amount of funds, $24.1 \%$ of the total amount, was allocated to social activities. $22.5 \%$ of total funds were allocated for the activities in the field of culture and art and $17.6 \%$ for sports projects. Most of the funds (40.36\%) were awarded through a public call/invitation. Sports competition are the most financed activity with $16 \%$ of the total amount, followed by organizational capacity building activities with $14.06 \%$ and activities aimed at raising the quality of life of people with disabilities with $9.64 \%$ (Office for the Cooperation with NGOs, 2017, pp. 3-45). It can be concluded that at national level, civil society organizations' programs and projects are increasingly seen as an investment in community and development of a society as a whole, and not as a cost.

In 2015, counties, the City of Zagreb, cities and municipalities allocated a total of EUR $113,262,536.37$ or $50.78 \%$ of total funds ${ }^{8}$. $66 \%$ of county's funds, $75 \%$ of city's funds and $40 \%$ of municipality's funds were awarded by public calls. All counties and the City of Zagreb allocate their funds based on strategic and/or program documents. While, only around $50 \%$ of cities and about $25 \%$ of municipalities have strategic documents based on which funds should be allocated (Office for the Cooperation with NGOs, 2017, pp. 3-45).

$5.87 \%$ of total funds were allocated from the county's budget using which 6.018 civil society organizations projects and programs were financed, which is $16.94 \%$ less than in 2014. 1.814 civil society organizations' projects and programs were financed by more than EUR 28 million $^{9}$ from the budget of City of Zagreb which represents $12.86 \%$ of total public funds. The largest amount of funds was allocated to the field of sport, almost $31 \%$ of the total public funds from county budget and $71.55 \%$ of the total amount from the budget of the City of Zagreb. Following is the area of culture and art, financed with a share of $20.14 \%$ of funds from county budget and with $11.39 \%$ of funds from the budget of the City of Zagreb, and the area of social activity ${ }^{10}$ funded with $11.37 \%$ of funds from county budget and $7.1 \%$ of total budget funds of the City of Zagreb (Office for the Cooperation with NGOs, 2017, pp. 3-45).

From city budgets EUR $52,954,371.97^{11}$ or $23.74 \%$ of total public funds was awarded. Using those public funds 8,721 civil society organizations projects and programs were financed. City of Split awarded $8.37 \%$ of total amount of funds from city budgets, City of Rijeka 6.5\% and City of Dubrovnik 5.2\%. $56,2 \%$ of total funds from city budgets or EUR $29,782,928.52$ is used for financing activities in field of sport followed by activities in field of protection and secure with share of $10,74 \%$, and projects and programs in a field of art and culture with $10,68 \%$. The largest share of funds (40.65\%) were allocated for the realization of public needs programs established by a special law. $40.21 \%$ of the funds were awarded through public calls. $10.1 \%$ funds are used

8 In 2014 EUR $18,032,837.25$ or more than $60 \%$ of total public funds was awarded by local selfgovernment units.

9 19,83\% less than in 2014

10 Financial support for people with disabilities, people with special needs and socially vulnerable groups

11 14,45\% less than in 2014 
for the implementation of public authority entrusted by the special law. While EUR $1,104,423.02$ or slightly more than $2 \%$ of the total allocated funds were by the decision of the mayor allocated outside the public call to unplanned activities (Office for the Cooperation with NGOs, 2017, pp. 3-45).

From municipal budgets $8.31 \%$ of total public funds (EUR 18,539,057.07) were allocated for implementation of 5,867 projects and programs. The highest amount of EUR 467,423.93 was allocated by the Municipality of Podstrana, which is $2.52 \%$ of the total amount of funds from municipal budgets, followed by the Municipality of Dugopolje with a share of $2.29 \%$ and the Municipality of Kostrena with a share of $1.56 \% .14$ municipalities declared that they did not allocate any public funds to civil society organizations in 2015. More than $40 \%$ of total funds from municipal budget were allocated for the activities in the field of sport, $26.12 \%$ for the activities in the field of the protection and secure, while projects and programs in the field of culture and art were financed by $13.90 \%$ of total amount of funds (Office for the Cooperation with NGOs, 2017, pp. 3-45).

142 companies owned by the Republic of Croatia and local and regional self-government units funded 2,231 projects with more than EUR 4 million. More than $80 \%$ of donations and sponsorships came from companies owned by the Republic of Croatia, such as Hrvatska elektroprivreda d.d. with 74,5\% of total amount, INA d.d. with 7,4\% and Croatian bank for reconstruction and development with $6.3 \%$. Among the companies owned by local self-government units, i.e. cities and municipalities, the highest amount was awarded by Zagrebački holding (26.4\%), followed by Vodovod i odvodnja Šibenik d.o.o. (10.37 \%), GKP Komunalac d.o.o. (3.36\%) i Montraker d.o.o. Vrsar (3,36\%). Most of the funds were awarded in the form of sponsorships, to be exact more than EUR 2.4 million, predominantly to the field of sport, followed by the area of social activity, and the area of culture and art. Donations and sponsorships from the public companies are mostly not awarded on the basis of strategic documents and in 2015 only a few companies awarded their donations on the basis of a public call, considering that the prescribed standards of planning, allocation and monitoring of allocated funds do not apply for them, which indicates a low level of awareness of need for transparent spending of public funds in public companies (Office for the Cooperation with NGOs, 2017, pp. 3-45).

36 tourist boards awarded $1.01 \%$ of total allocated funds from public sources for implementation of civil society organizations projects and programs in the field of tourism. The highest amount was awarded by the Tourist Board of the City of Zagreb with a share of $65.42 \%$, followed by Croatian National Tourist Board (8.71\%), Tourist Board of the City of Poreč (with a share of $5.66 \%$ ), Tourist Board of the Municipality of Medulin (3.89\%), Pula Tourist Board (2.44\%) and the Split-Dalmatia County Tourist Board (2.25\%) (Office for the Cooperation with NGOs, 2017, pp. 3-45).

This shows that even though civil society organizations are independent from the government and political life they highly rely on public funds. While income 
from social entrepreneurship is still underrepresented, pointing to the conclusion that this form of action is necessarily to be more systematically stimulated through the legal and tax system. Besides that, frequently public funds are awarded without any strategic documents based on which funds should be allocated and by knowing that the level of transparency of financial operations and financial discipline of associations is still unsatisfactory in Croatia, it necessary to ensure better monitoring and supervision of this group of entities.

\section{Review of Serbian and Slovenian experience}

Unlike accounting and financial reporting for entrepreneur which were harmonized through the application of IFRS/IAS, there are no special requirements for non-profit sector in the EU; national legislations are left to decide about the accounting standards and principles, as well as NGOs reporting requirements. So systems of accounting and financial reporting of NGOs significantly differs from one country to another, as well as in neighboring countries which make comparison between countries difficult. In this paper experience of Croatia is compared with experience of Serbia and Slovenia as neighbouring countries of which Slovenia is already an EU country and Serbia is non-EU country.

Civil society in Serbia is quite young. Most of the associations were established in 2000. All associations, no matter the size, apply double entry bookkeeping based on accrual accounting which makes analysis of financial potential of non-profit sector easier in comparison with Croatia where almost half of associations use single entry bookkeeping and another half use double entry bookkeeping. All associations need to electronically submit at least once a year balance sheet and statement of income with notes to Register of Associations which is led by Serbian Business Registers Agency (Velat et al., 2011, pp. 13-37). Thereat so called micro associations ${ }^{12}$ submit only balance sheet and statement of income without notes (Accounting Act, Serbian Official Gazette $62 / 2013,30 / 2018$ ). No data was found on how many of associations regularly fulfil their statutory obligation to submit financial reports so it is difficult to evaluate the level of transparency of civil sector in Serbia. Research result from 2011 show that most of the sources used for operating activities comes from project funding (28\%) and membership fees (23\%). In Serbia associations also can perform profit activities to generate revenue needed for their activities (Law on Associations, Serbian Offical Gazzette 51/09, 99/11), but only quarter of the total number of associations registered market activities in the Register of Economic Entities. Same as in Croatia revenues of social entrepreneurship are relatively poorly represented, i.e. only $13 \%$ of sources of associations is generated from performing market activities (Velat et al., 2011, pp.13-37).

In Slovenia in recent years the number of non-governmental organisations has been growing constantly. In compliance with the established practice only organisations that are submitting their annual reports to Agency of the Re-

12 In Serbia micro associations are associations that do not exceed two out of three following criteria: average number of employees is 10, business revenue of 700.000 EUR, average value of asset 350.000 EUR (Accounting Act, Serbian Official Gazette 62/2013, 30/2018) 
public of Slovenia for Public Legal Records and Related Services (AJPES) are perceived active and this is more than $95 \%$ of registered NGOs. In comparison with Croatia where only 70\% of NGO's fulfil their statutory obligation to submit financial reports, non profit sector in Slovenia show significantly higher level of transparency. According to data from May 2018 associations make up more than $87 \%$ of non profit sector in Slovenia (CNVOS, 2016). NGO's in Slovenia employ more than $0,8 \%$ total active population. As same as in Croatia, aggregated employment data and performance elements of associations in Slovenia are steadily increasing, suggesting that in economic terms, due to their non-market orientation, unfavourable economic conditions have not adversely affected the activities of associations. According to data from 2007 $53 \%$ of total revenues is generated from providing services and only $27 \%$ from public funds and 13\% from private donations (Kolarič et al. 2002; ČrnakMeglič 2008; AJPES 2010 according to Rožić, 2015, p. 734). The amount of funds acquired by non-governmental organisations from public sources had been increasing till 2011, when for the first time, a slight drop occurred. Since 2012, the amount has been fluctuating, and in 2016 more than $65 \%$ of total revenue is generated from other than public funds sources, such as donations, memberships, sales revenue and the like. Thereat In of all funds remitted by budget users, $66.79 \%$ were allocated to non-governmental organisations to which the state has acknowledged to be acting in the public interest (CNVOS, 2016). These data is perceived as government is not supporting enough development of civil society sector in Slovenia.

\section{Conclusions and recommendations}

The development of a civil society, as part of a non-governmental non-profit sector, is one of the key indicators of the degree of development of a country's democracy. In addition, citizens' associations with their multitude and heterogeneity of activities represent the fundamental infrastructure of civil society and are the dominant part of the non-governmental non-profit sector. Due to countries, particularly transitional and post-transitional countries, dedicate special attention to institutional and legislative creation of conditions for their establishment and operation which is reflected in the creation of a broad and liberal legal framework, certain tax benefits, institutional support and public funding. Although citizen's associations operate predominantly on volunteer basis, the viability of the activities of citizen associations and other non-governmental non-profit organizations is conditioned by the availability of appropriate economic and financial resources. Citizens' association's sources of funds vary and, in accordance with their non-market and non-profit orientation, are only to a lesser extent generated on the market in the sphere of social entrepreneurship.

The development, performance and importance of the non-profit sector is primarily evaluated by non-financial, qualitative criteria of their influence on political decisions and their contribution to the development of society as a whole, while systematic monitoring of economic and human potential and financial sustainability of citizen's associations is absent. The research results 
presented in this paper show a significant number of citizens' associations and significant regional diversity of their activity in relation to the number of inhabitants. Also, research results show that the degree of financial discipline and formal legal arrangements are still low. This is reflected in the disproportion of the total number of registered associations in relation to the number of associations that have aligned their statues with the Law on Association and a significant number of associations that did not fulfil their statutory obligation to submit financial statements. These facts make comprehensive economic financial analysis of the entire group of associations difficult. However, available data show that associations represent a respectable socio-economic segment in the Republic of Croatia. Annual revenues and assets of this group of legal entities are continuously increasing and continuously exceed HRK 5 billion, while effective employment, expressed in hours of work, reaches almost $1 \%$ of the total number of employees in the Republic of Croatia. Although to a large extent based on voluntarism and private sources of funding, public funds still represent the most important source of financing civil society organizations activities, while income from social entrepreneurship is still underrepresented.

Systems of accounting and financial reporting of NGOs significantly differs from one country to another, as well as in neighbouring countries which make comparison between countries difficult and makes it hard to evaluate current situation of civil society sector. But some conclusions and recommendation can be made. Government should definitely support development of civil society sector but public funds should me awarded based on the strategic or other similar documents and level of awareness of need for transparent spending of public funds should be increased. Social entrepreneurship results with a lot of different benefits for the whole society so it should be more systematically stimulated through the legal and tax system. Civil society sector represent a respectable socio-economic segment that should not be neglected in the defining macroeconomic management at the national level. And even though it has low fiscal potential there is high possibility of the exploitation of their economic and financial unattractiveness and their relatively privileged tax position so it is necessary to ensure better monitoring and supervision of this group of entities. 


\section{References}

Accounting Act. Serbian Official Gazette 62/2013, 30/2018.

Act on Financial Operations and Accounting of Non-Profit Organizations. Official Gazette 121/2014.

Bežovan, G. (2002). Struktura civilnog društva u Hrvatskoj. Politička misao, 39(1), pp. 63-87.

Bežovan, G. (2004). Civilno društvo. Zagreb: Nakladni zavod Globus.

Bežovan, G. and Ivanović, M. (2009). Razvoj civilnog društva u Hrvatskoj. Zagreb: UNDP Croatia. At: <http://programjako.info/wp-content/uploads/2009/01/ UNDP_RazvojCivilnogDrustvaUHrvatskoj.pdf>, accessed 15 March, 2017.

CNVOS. (2016). At< https://www.cnvos.si/en/>, accessed 5 July 2018.

Croatian Bureau of Statistics. (2011). Population contingents, by towns/ municipalities. At< https://www.dzs.hr/Hrv/censuses/census2011/results/ htm/H01_01_03/H01_01_03.html>, accessed 8 August 2017.

Croatian Bureau of Statistics. (2011b). Employed by occupation, age and sex, by towns/municipalities. At<http://www.dzs.hr/Hrv/censuses/census2011/ results/censustabsxls.htm>, accessed 27 March 2017.

Croatian Bureau of Statics (ny). Sektorska klasifikacija institucionalnih jedinica, (S.13). At <http://www.dzs.hr/app/sektorizacija/Documentation/ SektorskaKlasifikacija.pdf>, accessed 15 March 2017.

European Commission. (2013). European system of accounts - ESA 2010. Classification of the purposes of non-profit institutions serving households (COPNI). At <http://ec.europa.eu/eurostat/web/products-manuals-andguidelines/-/KS-02-13-269>, accessed 15 March 2017.

Instructions from the Central Tax Administration Office. KLASA: 410-01/1501/1590, URBROJ: 513-07-21-01/15-1. Ministry of Finance of Republic of Croatia.

Law on Association. Official Gazette 74/17, 70/17.

Law on Associations. Serbian Offical Gazzette 51/09, 99/11.

Ministry of Public Administration. (2017). Statistički prikaz Ministarstva uprave broj 7. At <https://uprava.gov.hr/UserDocslmages//Statisti\%C4\%8Dki\%20 prikaz//Statisti\%C4\%8Dki\%20prikaz-\%20final.pdf>, accessed 8 August 2017.

Office for the Cooperation with NGOs (2017). Izvješće o financiranju projekata i programa organizacija civilnoga društva iz javnih izvora u 2015. godini.

At <https://udruge.gov.hr/UserDocsImages/dokumenti/Izvjesce\%200\%20 financiranju\%20projekata\%20i\%20programa\%200CD-a\%20u\%202015\%20 -\%20sve\%20razine\%20-\%20final.pdf>, accessed 8 August 8, 2017.

Register of Associations of Republic of Croatia. Ministry of Finance.

Regulation on the Criteria, Standards and Procedures for Financing and Contracting Programs, and Projects of Public Benefit Interest Implemented by Associations. Official Gazette 26/15.

Rožič, P. (2015). Civic Dis-Embeddedness? Explaining Twenty-Five Years of Weak Civil Society in Slovenia. Bogoslovni vestnik, 75(4), pp. 727-740.

The Rulebook on Determining Budget and Extra-budgetary Users of the State Budget and Budget and Extra-budgetary Users of the Budget of Local and Regional Self-Government Units and on the Method of Keeping the Register of Budgetary and Extra-budgetary Users. Official Gazette 128/09, 142/14. 
Vašiček, D., Sikirić, A.M. and Čičak, J. (2017). Economic and financial aspects of the operation of non-governmental organizations in Croatia. In Proceedings of the 6 . International scientific symposium: Economy of eastern Croatiavision and growth, 25-27 May, Faculty of Economics, University Josipa Jurja Strossmayera in Osijeku, pp. 758-767.

Vašiček, V. and Vašiček, D. (2016). Računovodstvo proračunskih i neprofitnih organizacija. Rijeka, Zagreb: Ekonomski fakultet Sveučilišta u Rijeci and TIM4PIN.

Velat, D. and other employees of Civic Inciative (2011). Procena stanja u sektoru organizacija civilnog društva (OCD) u Srbiji. Beograd: Građanska Incijativa. 